\title{
A Brief History of The National Museum Herat
}

Museums are treasure houses of national pride and symbols of cultural value that are crucial tools in the process of intellectual development of both the cities and countryside. As the research and writings of numerous scholars have suggested, the ancient history of Herat and the creative minds of the Heratian/Aryan ${ }^{1}$ ancestors have been a positive and informative story of civilization in Afghanistan.

\section{EARLY YEARS OF THE HERAT MUSEUM COLLECTIONS}

The collections of the National Museum Herat have a long locational history. The museum was first established in an old Timurid building in the Chahar Bagh area almost a century ago, in 1925 CE (1302 AH Islamic calendar), by Ghorbandi Shuja-ul-Dowla, then governor of Herat. In $1934(1315 \mathrm{AH})$ the city expanded, the Timurid building was destroyed, and the museum collections were moved to the Herat Hotel. Then in 1945 (1326 AH), they moved to the Herat Municipality, followed by the Ministry of Information and Culture's Independent Directorate. All of the historical artifacts were moved again in 1965 (1340 AH), by decision of authority, to the lobby of the governor's headquarters for storage. In 1994, Ismail Khan brought the collections to the Qala-e Ikhtiyaruddin, (see Khushbeen \& Baba Timuri 2008), the citadel of Herat that might date as far back as the Achaemenid period (ca. 500 BCE; cf. Franke 2008b: 77$82)$.

Unfortunately, through the decades of violence and civil unrest, the museum had been destroyed and looted several times. Its most precious and rare artifacts, those that were created by the innovative minds of the ancient inhabitants, were stolen. The looted artifacts include, but are not limited to, 1,665 gold, silver, and copper coins, a number of old rifles dating to the $15-16^{\text {th }}$ century CE $\left(9^{\text {th }}\right.$ century SH), 45 handwritten manuscripts, and other rare historical objects such as paintings in the traditional miniature style (Khushbeen \& Baba Timuri 2008: 8). During the era of Taliban rule, 110 unique pre-Islamic sculptures that introduced cultural identities of the ancient people to today's generation were, sadly, damaged and/or destroyed (ibid.).

Between 2004 and 2005 (1383-1384 AH), Ismail Khan, reappointed as governor of Herat, had the museum collections moved several more times until they finally returned to the newly demined Qala-e Ikhtiyaruddin (Khushbeen \& Baba Timuri 2008: 9). The destructive outcomes of the Civil War and Taliban period were not the only threats to the artifactual heritage of Herat; years of neglect, poor preservation, and constant movement of the collections left them in a terrible state. Furthermore, unprofessional storage conditions in most of the numerous housing facilities used for the artifacts over the decades had caused them to be badly affected by oxidation, salt, dust, humidity, and erosion.

\footnotetext{
1 The proper nouns 'Herat' and 'Aryan,' like 'Iran,' are both etymologically derivative of 'Haraiva' in Old Persian and 'Harê' in Middle Persian, similarly to the name of the river, the Hari Rud, that flows through Herat (Ball 2008: 200; Haase 2008: 19).
} 


\section{RESTORATION OF THE NATIONAL MUSEUM HERAT}

In light of the tragic events and losses due to decades of conflict, an old and famous saying can be consoling: "We have fallen, but still we are the same people."

The Herat Museum still has 498 records that contain 2,500 pieces that span the chronological range from the Neolithic Period to the modern era. The collection includes objects from the Chalcolithic Period, the Bronze Age, the Iron Age, the Bactrian period, the Achaemenid period, the Greco-Bactrian period, the Kushan period, the Hephthalite period, the time of Ashoka, and the Islamic period that covers the reigns of the Saffarids, Tahirids, Samanids, Ghaznavids, Seljuks, Ghorids, Khwarezms, Mongols, Timurids, Shybanids, and Safavids. Furthermore, there are an additional 289 cards that contain lists of books, manuscripts, and important documents that demonstrate a positive view of the region's history to both the local population and that of the world.

To protect and preserve these substantial, surviving parts of the collections, in 2007 (1386 AH) the Herat Museum began a collaborative restoration effort involving the Ministry of Information and Culture, Dr. Masoudi, director of the National Museum of Afghanistan, Dr. Ute Franke of the German Archaeological Institute, the Afghanistan Archive, and the Institute of Islamic Art Museum in Berlin. Through the deployment of professional, experienced teams from the Berlin Museum and the National Museum in Kabul, it became possible to repair, clean, preserve, count, and register the Herat Museum collections.

Four years later, on January 14, 2011 (10/24/1390 AH), The National Museum Herat opened its doors to the public and it has since welcomed a great number of international and national visitors. ${ }^{2}$ Due to the increased demand for visitation, the expansion of the current museum and/or building a new museum seem urgent. To respond to this urgent need, cooperation of relevant departments of the Ministry of Information and Culture is critical.

\section{COLLECTIONS IN CONTEXT}

The region of Herat, located in western Afghanistan along the Iranian border, has at least limited evidence of occupation from the Bronze Age until the modern day. The Bronze Age components of the Herat Museum collections, generally unprovenienced, were originally thought to have come from elsewhere in Afghanistan, such as Tashqurgan or Baghdis, but the more recent discovery of $3^{\text {rd }}$ and $2^{\text {nd }}$ millennium BCE sites such as Gulran (Franke 2008b: 74) have connected the northeastern part of the region to the Bactria-Margiana Archaeological Complex that spans northern Afghanistan and southern Central Asia (Franke 2008a: 31). A shared material culture can be seen in funerary objects such as carved stone hourglass-shaped "miniature columns" or weights. Connections to both the Helmand River Valley civilization and the Indus Valley civilization are also seen in Bronze Age artifacts from the Herat Museum such as ceremonial, twisted-shaft, flat blades (ibid.: 32).

\footnotetext{
2 The weekly revenue generated by the Museum, 200,010 AFN, is deposited with the Treasury Department and receipts are stored locally.
} 
Historically, the city of Herat was mentioned (as 'Haroyu') in the Zoroastrian holy book the Avesta that dates to the $1^{\text {st }}$ millennium BCE; in Achaemenid sources from around the $6^{\text {th }}$ century BCE (as 'Haraiva'); in the writings of Herodotus ca. 480 BCE; and then by Strabo, Arrian, and Pliny regarding Alexander the Great's conquest of 'Areia' (ibid.: 29-30). In later antiquity Herat was an important trade town located at the crossroads of the Silk Route and the northern route to Bukhara (Haase 2008: 19), and appears in Parthian and Sasanian sources as well. However, material evidence for settlement of the region before the Islamic period had been scant before the German Archaeological Institute conducted their archaeological survey from 2005-2007 (see Franke 2008b). Under the Ghorids (12 ${ }^{\text {th }}$ century CE) Herat became a capital city, and it later flourished during the period of Timurid rule (15 ${ }^{\text {th }}$ century CE; Ball 2008: 200).

The culmination of the German archaeological efforts in Herat was excavation at Qala-e Ikhtiyaruddin itself, complementing both the regional survey and the restoration of the museum. Early Islamic levels of the citadel date to the Ghaznavid period $\left(10^{\text {th }}\right.$ century $\left.\mathrm{CE}\right)$, but two trenches uncovered a large, nearly solid, brick structure and its pre-Islamic antecedents. The earliest layers beneath the brick massif featured $1^{\text {st }}$ millennium BCE occupational debris such as a bilobate, socketed bronze arrowhead, unglazed, undecorated pottery, grinding stones, a gaming piece, hearths, and so forth. These are the earliest material remains so far evidenced in the city of Herat (Franke 2008b: 80-82). The question of whether the foundation of the citadel dates to the Achaemenids, Alexander, or the Hellenistic period, however, remains unanswered (ibid.: 77).

The display collections of the Herat Museum, from Bronze Age alabaster lamps (Franke ed. 2008: P1. 65) to the $18^{\text {th }}$ century CE Divan of Bidel Dahlavi (Franke ed. 2008: Pl. 115), are arranged chronologically and are housed in a part of the citadel whose long, pointed-arch hallways run perpendicular to the uphill slope of the building's foundation. Every gallery is laid out latitudinally, each one a step higher than the last. As one moves upward through the galleries, one's imagination also moves forward through time, as if in an archaeological step trench. In one of the most extensive galleries, the magnificent pottery, metalwork, and glasswork of the medieval Islamic period truly help to contextualize the most visible remains of the Qala-e Ikhtiyaruddin, and, vice versa, the restored ruins of the surrounding citadel help to give context to the artifacts. ${ }^{3}$

\section{CHALLENGES FOR THE FUTURE}

Recent efforts in Afghanistan have highlighted the lack of experience and inadequate access to professional training in cultural heritage preservation that Afghans face. On the other hand, they do care about preservation of their national cultural heritage and are willing to educate themselves on the issue. It has been noticed that some visitors become concerned as soon as they see the Buddhist sculptures in the lobby of the exhibition hall, but as soon as it is explained to them that the exhibition is for education purposes, so that Afghans can learn how their ancestors lived before Islam, their concern fades away. In Afghanistan, in comparison to middle class, the broader populace seems to have a more positive view toward the historical and cultural values of historical heritages. As a starting point, we must elevate the importance and value of cultural

\footnotetext{
${ }^{3}$ For discussion of an earlier but similar approach to the Museum of Islamic Art in Ghazni, situated in the the Timurid 'Abd al-Razzaq mausoleum, see Filigenzi, this volume, p. 6.
} 
heritage amongst the middle class, and develop new strategies to encourage the broader population to value this patrimony.

Enemies of the Afghan homeland have created challenges, obstacles, and difficulties in various historical periods for cultural heritage preservation and it is a daunting task, now as ever. There is a long, difficult road ahead in order to reach the desired destination of progress and expansion. We hope that both regional neighbors and the friendly, partner countries around the world lend their utmost efforts for the return of Afghanistan's confiscated artifacts that had been smuggled out of the country in recent years. For a long time the Herat Museum was assisted by the Berlin Museum's Islamic Art Institute, and this partnership was effective in the protection of the Herat Museum collections. Right now, significant numbers of collected objects still need identification and repair, but the Herat Museum lacks the technical self-sufficiency to perform such work. Thus, we are hoping that the German team once again comes to the Museum and helps us to take care of these valuable objects.

Establishing a database, collecting and documenting objects, registering list cards, and diagnosing the affected objects of the Herat Museum, need skillful and professional consideration in accordance with international standards. The official museum staff and the authorities are fighting against ongoing threats to the Herat Museum, but they need to enhance their knowledge and professional capacity in order to succeed. Providing opportunities to achieve this goal is a priority.

It is now more than ever an urgent task to exploit the a broader definition of 'museum' and establish a relationship between the public and the exhibitions, while still maintaining and managing the artifacts in storage for transfer to the custodians of the next generation. The following are the permanent responsibilities of the museum officials: primary safety; methods of safety procedure; distinguishing between helpful and harmful methods of preservation; environmental standards; maintenance of rooms, depots, and labs; procedural safeguarding of the artifacts; and continuous attention to public exhibitions as a public awareness service and education for visitors. In addition to routine daily activities, the Herat Museum is in contact with relevant institutions and uses their potential and available resources for better protection of cultural heritage. And lastly, on behalf of the National Museum Herat, I thank and appreciate cooperation and assistance of the international community and cultural institutes provided to us for protecting our cultural heritage. I hope that this cooperation continues in the future. 


\section{BIBLIOGRAPHY}

Ball, W.

2008 The Monuments of Afghanistan: History, Archaeology and Architecture, London.

Franke, U., ed.

2008 National Museum Herat - Areia Antiqua Through Time, Berlin.

Franke, U.

2008a "Prehistory: Beyond Alexander the Great," in National Museum Herat - Areia Antiqua Through Time, Franke, U. ed., Berlin: pp. 29-37.

2008 b "In Search for the Historical Roots of a Region," in National Museum Herat Areia Antiqua Through Time, Franke, U. ed., Berlin: pp. 71-85.

Haase, C.-P.

2008 "Herat: An Islamic Metropolis," in National Museum Herat - Areia

Antiqua Through Time, Franke, U. ed., Berlin: pp. 19-27.

Khushbeen, Y. \& B. Baha Timuri.

2008 "National Museum Herat: Its History," in National Museum Herat - Areia Antiqua Through Time, Franke, U. ed., Berlin: pp. 7-10. 